\title{
Expression on Virtual Communication System
}

\author{
OTakashi TORIIZUKA, Kageyu NORO \\ (School of Human Sciences, WASEDA University)
}

はじめに

現存型のビデオコミュニケーションシステムで は、カメラとモニタが一致していないために、自 然な映像が相手に伝達され得ない（Fig. 1）。この 問題を解決するために筆者らはアイコンタクトビ デオコミュニケーションシステムを開発した。こ のシステムはカメラとモニタが一致しているため 相手と梘線を交錯させながら会話ができるように なったのである。さらにこのように梘線を交錯さ せることのできるようなシステムの有用性が検証 された1)。

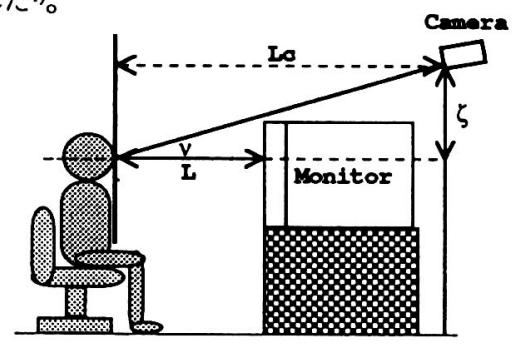

Fig. 1 現存型システムのParametrlc Model

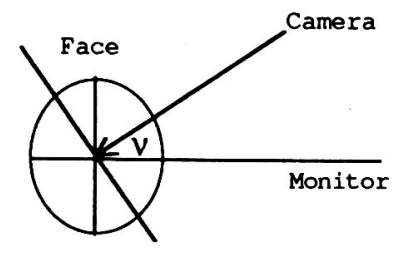

Fig. 2 現存型システムの頙・カメラ・モニタの関係

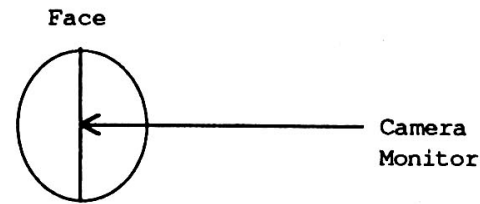

Fig.3 䧗場感通信システムの顔・カメラ・モニタの関係
実験

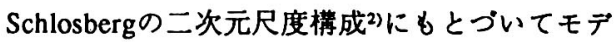
ルにFig. 5の6つの表情をとらせ、Fig.4のようなシ ステムで撮影した。撮影された表情を被験者（男 女30人）にビデオにて呈示し、表情を判別させ た。その際、選択式の回答用紙を用意した。また モデルにはEkmanの定義》による表情をあらかじめ 十分に練習させておいた。なお本実験では表情が 伝達されたことは被験者が表情を判別できたこと と定義して実験をおこなった。

結果

結果をFig. 6、Fig. 7に示した。

\section{考察}

Fig. 6で明らかな違いがみられた3表情について考 察する。「幸福」の表情は、現存型システムで見 ると、なにかの表情であることは分かるが、その 表情が何の表情か判別することのできない被験者 が多かった。表情が微妙なたけにはっきりと表情 を判別できなかったと推測されよう。「怒り」

「軽茂」の両表情は、顔の下半分とくにロ元に大 きな特徵をもつ。現存型システムでは顔の下半分 （Fig.2中の斜線部）が、カメラに収むりにくく

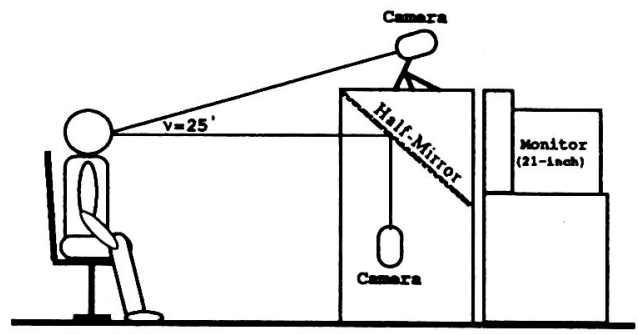

Fig. 4 撮影に使用したシステムのParametric Model 

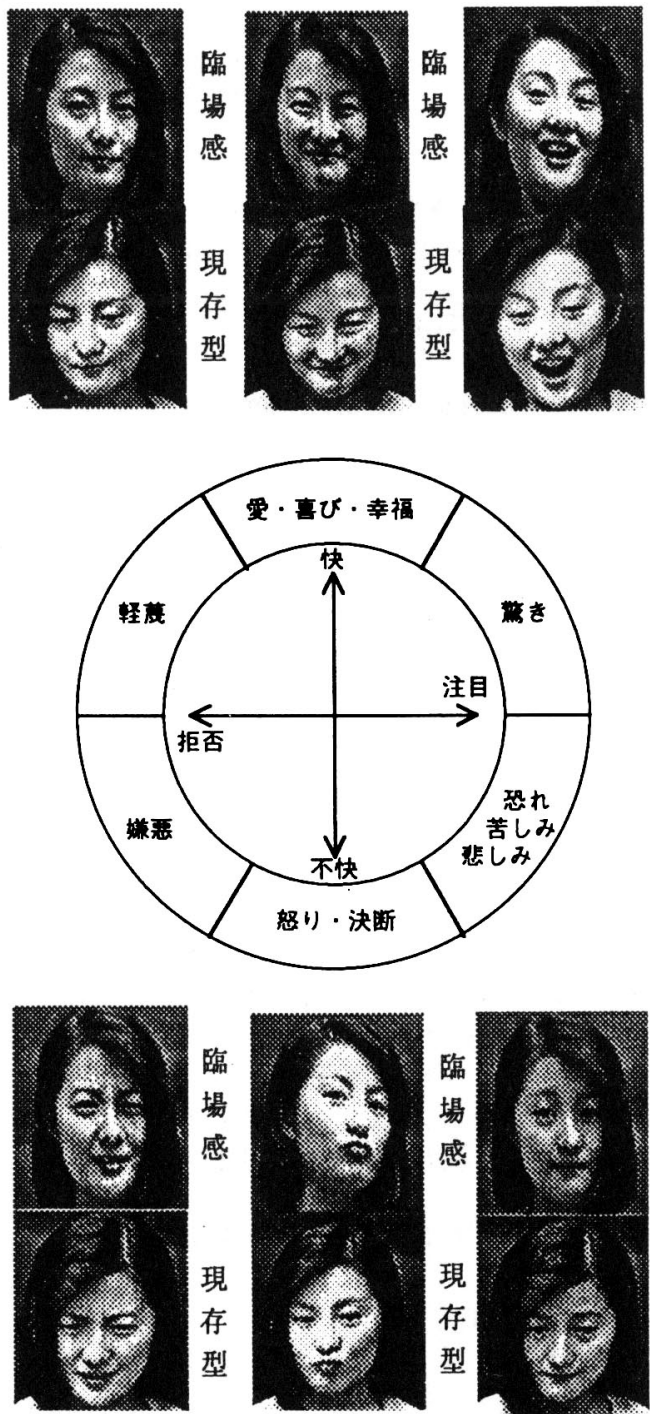

Fig. 5 Schlosbergによる表情の二次元粠成のモデル 衰情は6つの表情にカテコラライズきれる。写真は、おのおのの上

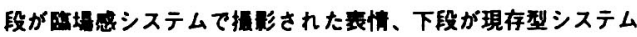
で蛰影された器情。

なっている。このような理由て、顔の下半分に特 徵をもつ表情は、伝達されにくくなっているもの と推測される。しかし、臨場感通信システムで は、Fig. 2のעの歪みが無いので、正確な顔の表情 が相手に伝達できるようになったのである。

本実験で全く異なった6表情について判別させ る実験をおこなった。このような全く異なった表

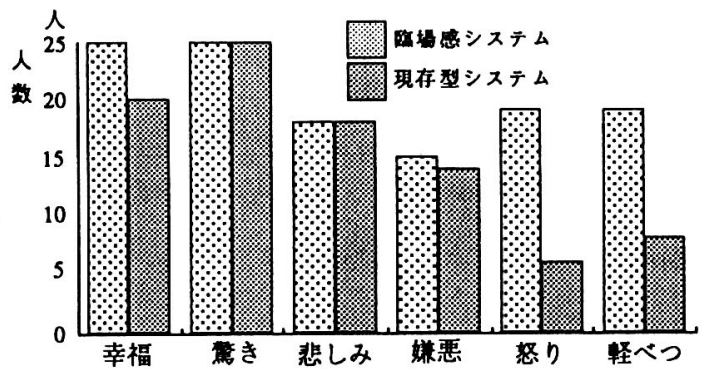

Fig. 6 表情を判別することのできた人数 明らかな连いが認められたのは「幸楅」「怒り」「锃 藏」の3表情であった ( $0<0.05)$ 。現存型では、「怒り」 「怪べつ」の区別がつかない被騃者が多かった。

人

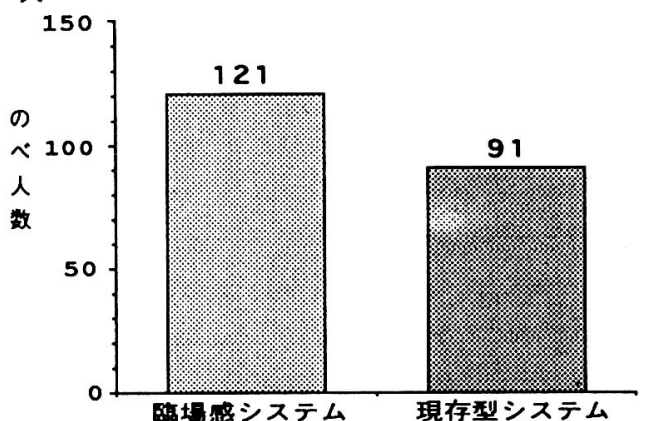

Fig.7表情を判別することのできた人就（各々の表 を判別できた人数の和、すなわちのべ人数）

䧔感システムではのべ121人だったが、現存型システムでは のべ91人であり、明らかに逢いが鴊められた $(p<0.05) 。$

情どうしであると臨場感システムを用いれば简単 に判別できる。しかし現存型システムではそのよ うな表情でさえも判別しにくいのである。このこ とは図7に示されている。つまり䠛場感通信システ ムは、表情伝達可能なシステムとして、従来より も改善されたシステムとなったことがわかった。 しかし、今後、微妙な表情の伝達度を調べるため には、さらに微妙な表情どうしを比較判別させる 必要がある。

\section{参考文献}

1) 鳥居㛣致：見つめあえるビデオコミュニケーションシステ ムの試作と規線の解析、日本人間工学会第33会大会淇演集 1992 2) H. Schlosberg : The Discription of Facial Expressions in Terms of Two Dimensions, Jounal of Experimental Psychology, 1952

3) P. Ekman : Facial Action Cording System, Palo Alto, CA , Consulting Psychologist Press , 1978 